\title{
Day and night ichthyoplankton assemblages and zooplankton biomass size spectrum in a deep ocean island wake
}

\author{
Iain M. Suthers ${ }^{1, *}$, C. T. Taggart ${ }^{2}$, D. Rissik ${ }^{1}$, M. E. Baird ${ }^{3}$ \\ ${ }^{1}$ School of Biological, Earth \& Environmental Science, University of New South Wales, Sydney, New South Wales 2052, \\ Australia \\ ${ }^{2}$ Department of Oceanography, Dalhousie University, Halifax, Nova Scotia B3H 4J1, Canada \\ ${ }^{3}$ School of Mathematics, University of New South Wales, Sydney, New South Wales 2052, Australia
}

\begin{abstract}
Zooplankton size and larval fish assemblages were compared between locations in the incident free stream and the island wake of Cato Reef, in the south Coral Sea over $6 \mathrm{~d}$ in February 1993. Weak incident northward flow of $0.3 \mathrm{~m} \mathrm{~s}^{-1}$ generated a wake on the lee side of the reef. Total abundance or larval fish diversity did not differ between the lee side and the wake. Myctophids and gonostomatids dominated the catch ( $85 \%$ ), while reef-associated taxa represented $<2 \%$ of the total. There were significantly fewer reef fish larvae in the wake $(\sim 25 \%)$ than in the free stream, suggesting that reef-related settlement and/or predation may explain the difference. Most of the ichthyoplankton (58 families) were associated with the thermocline (ca. $50 \mathrm{~m}$ depth) during day and night. We found significantly steeper slopes of the normalised biomass size spectrum (NBSS, derived from an optical plankton counter) in the wake compared to in the free stream and near the thermocline. The slope was significantly correlated with the shape parameter of the Pareto distribution $(r=0.90)$, with local light attenuation and with smaller (318 to $883 \mu \mathrm{m}$ equivalent spherical diameter) zooplankton biomass, consistent with the NBSS slope being a proxy for secondary production. The slope did not vary significantly between day and night despite a $30 \%$ daytime reduction in total zooplankton biomass. Steeper slopes were significantly correlated with a greater abundance of larval myctophids and gonostomatids, possibly by fish seeking productive areas and by top-down removal of larger zooplankton.
\end{abstract}

KEY WORDS: Coral Sea $\cdot$ Myctophidae $\cdot$ Optical plankton counter $\cdot$ Diel vertical distribution

\section{INTRODUCTION}

Isolated islands or atolls can serve as examples of larger and more complex ecosystems (e.g. Cowen \& Castro 1994, Stapp et al. 1999). Within the flowdisturbed lee (wake) of isolated reefs and islands, the biological effects of nutrient upwelling is evident, without the confounding effects of terrestrial run-off or tidal mixing that occurs along the mainland coast. The 'island mass effect' (Gilmartin \& Revelante 1974), whereby regions of flow disturbance in the lee of an island result in enhanced levels of nutrients and chlorophyll, is particularly dramatic in the oligotrophic tropical ocean (e.g. Genin \& Boehlert 1985, Heywood et al. 1990, Boehlert et al. 1992).

Wake-induced upwelling and nutrient enhancement (Coutis \& Middleton 1999) should increase the production of phytoplankton. Consequently, the biomass of small zooplankton should increase the negative slope of the zooplankton biomass size-frequency distribution, i.e. the biomass size spectrum (BSS). In this case, the slope is an index of secondary production. With continuing production, biomass should be transferred via predation to large particle sizes, thus reducing the 
slope while increasing the total biomass and the intercept of the BSS. Alternatively, ichthyoplankton could feed on larger prey particles (Rissik \& Suthers 2000), thus increasing the BSS slope via top-down control (Moore \& Suthers 2006).

The decreasing biomass of zooplankton as a function of increasing size underpins the BSS theory (Sheldon et al. 1977, Platt \& Denman 1978; reviews: Heath 1995, Kerr \& Dickie 2001). Plankton are particularly amenable to assessing variation in the BSS over a broad range of sizes when measured using in situ and automated plankton counters, e.g. the optical plankton counter (OPC; Herman 1988, Sprules et al. 1992). Further, comparisons of different BSS are achieved at logarithmic scales by using the normalised BSS (hereafter NBSS), whereby the biomass $(M)$ estimate in each class or category is divided by its corresponding size $(L)$ interval (Platt \& Denman 1978). Rodriguez \& Mullin (1986a) describe a range of normalised slopes around the theoretical value of -1.2 (Platt \& Denman 1978), and were the first to observe that the slope can vary systematically and meaningfully among seasons, depths and between day and night-even in such an oceanographically stable ecosystem as the North Pacific Central Gyre (NPCG).

The negative slope of the zooplankton NBSS can theoretically be ascribed to the competing rates of respiration/growth (Platt \& Denman 1978) or mortality/ growth (Heath 1995), subsequently unified by Zhou \& Huntley (1997) for the zooplankton domain. They demonstrated that the slope matched the ratio of the intrinsic rate of increase in abundance to the weightspecific, individual growth rate. Their approach is appropriate when there are significant deviations from a linear slope, such as the biomass 'domes' corresponding to trophic categories observed by Sprules \& Goyke (1994) in the Great Lakes. An alternative to the NBSS and a widely used statistical model is the Pareto distribution (Vidondo et al. 1997), particularly useful for non-linear distributions, which we use in the present paper for comparisons with the standard slopes from the NBSS.

Our aims were to examine the spatial and day/night variation in the zooplankton NBSS and in the ichthyoplankton assemblage around an isolated island (Cato Reef) and its associated island wake (Coutis \& Middleton 1999) in the oligotrophic south Coral Sea. Zooplankton biomass is known to be enhanced within the island wake of Cato Reef (Rissik et al. 1997). In this system, enhanced secondary production was inferred from the condition of pelagic juvenile myctophid fish (Suthers 1996) and gut fullness (Rissik \& Suthers 2000). The size of particles found in the gut was in the mid- to large size range of particles found in the ocean. However, the relation between the ichthyoplankton assemblage and the zooplankton size assemblage is unknown. Our aims were to re-examine the island mass effect on the zooplankton size relations provided by Rissik et al. (1997) around Cato Reef with respect to the NBSS and the Pareto distribution and the temporal and spatial variation. We then interpret the NBSS slope through comparison with light attenuation, the small zooplankton biomass and the abundance of larval and pelagic juvenile fish. We assess the effect of the wake on the vertical structure of ichthyoplankton assemblages spatially and over 3 replicate nights. There may well be an ichthyoplankton assemblage that is characteristic of nutrient uplift and enhanced zooplankton biomass. Our overall goal was, for the first time, to draw together the ichthyoplankton and the zooplankton NBSS in a biologically meaningful manner.

\section{MATERIALS AND METHODS}

Study area. Cato Island is a low-relief cay with a small shallow lagoon, located in the SW Coral Sea $\left(155.53^{\circ} \mathrm{E}, 23.25^{\circ} \mathrm{S}\right)$, approximately $375 \mathrm{~km}$ east of Gladstone on the Queensland coast (Fig. 1). Currents in the area arise from the East Australian Current or wind forcing and can exceed $1 \mathrm{~m} \mathrm{~s}^{-1}$ for periods of 2 to 3 wk (Coutis \& Middleton 1999). During our cruise from 14 to 21 February 1993, currents recorded by 2 Aanderra current meters deployed near the $100 \mathrm{~m}$ isobath were northward at around $0.3 \mathrm{~m} \mathrm{~s}^{-1}$ for $3 \mathrm{wk}$ prior to our sampling, with a very weak tidal signal (J. H.

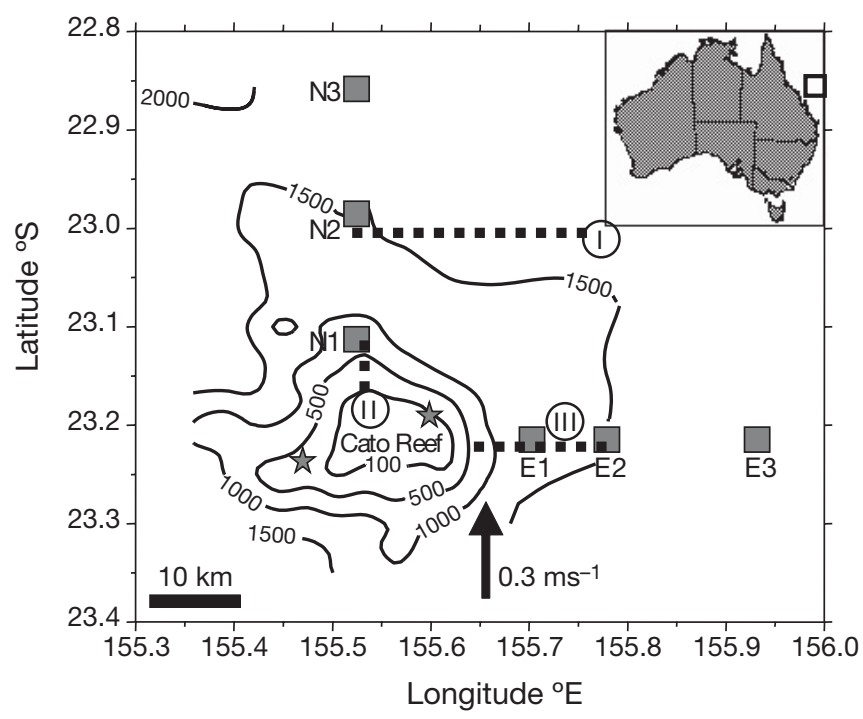

Fig. 1. Main hydrographic and zooplankton transects (I, II and III) around the Cato Reef Island, showing bathymetry and the sampling stations of the free stream to the east (E1, E2, E3) and of the uplifted region to the north (N1, N2, N3). Current meter moorings indicated with a star 
Middleton, University of New South Wales, unpubl. data). There was evidence from 1 current meter of the passage of Cyclone Oliver, $7 \mathrm{~d}$ before our sampling, when the currents were reversed on some days. The surrounding bathymetry is approximately $3000 \mathrm{~m}$ deep, gently rising to $1500 \mathrm{~m}$ and within $20 \mathrm{~km}$ of Cato Reef it reaches the $300 \mathrm{~m}$ isobath (Fig. 1). The $50 \mathrm{~m}$ deep, $20 \mathrm{~km}$ diameter bank extends $7 \mathrm{~km}$ north of a sparsely vegetated sand cay. Hutchison Rock is located on the eastern tip of the bank. The rocks and cay are significant rookeries for seabirds. There is virtually no freshwater run-off from the cays.

The flow around Cato Reef, under the influence of the $0.3 \mathrm{~m} \mathrm{~s}^{-1}$ northward current observed during our cruise, was reported by Coutis \& Middleton (1999) as a 'weak incident flow' case. Nevertheless, a wake zone consisting of weak and variable currents (derived from the vessel's Acoustic Doppler Current Profiler, ADCP) extended $70 \mathrm{~km}$ northwest of the island and persisted to depths of approximately $80 \mathrm{~m}$. At $17 \mathrm{~m}$ depth there was evidence of a return flow within the wake zone. Surface temperatures were $>27^{\circ} \mathrm{C}$, and a strong thermocline was evident around $50 \mathrm{~m}$ depth $(25$ to $24^{\circ} \mathrm{C}$ ), thus capping the uplift of isotherms by only $40 \mathrm{~m}$. Within the wake, the subsurface chlorophyll maximum ( $>0.25 \mathrm{mg} \mathrm{m}^{-3}$ ) was 2 - to 3 -fold thicker than outside the wake. The depth-integrated chlorophyll just $20 \mathrm{~km}$ north was $\sim 40 \mathrm{mg} \mathrm{m}^{-2}$ and declined to a background of $\sim 24 \mathrm{mg} \mathrm{m}^{-2}$ at $47 \mathrm{~km}$ downstream (Coutis \& Middleton 1999).

Sampling procedure. Based on the circulation, we established 1 eastern sampling transect in the free stream with 3 sampling stations (E1, E2, E3, Fig. 1) and 1 northern transect in the wake, also with 3 stations (N1, N2, N3, Fig. 1). Each transect was sampled on each of 3 ('replicate') nights during a new moon (21 February) phase with at least $50 \%$ cloud cover. We collected replicate ichthyoplankton samples at night using a neuston net $(75 \times 75 \mathrm{~cm}, 330 \mu \mathrm{m}$ mesh) and a subsurface multiple opening-closing net $\left(1 \mathrm{~m}^{2}, 333 \mu \mathrm{m}\right.$ mesh with $200 \mu \mathrm{m}$ mesh bag cod-ends) deployed over 3 depth strata of $30 \mathrm{~m}$ : 105 to 75,75 to 45,45 to $5 \mathrm{~m}$, referred to hereafter as the 90,60 and $30 \mathrm{~m}$ depth bins, respectively. The metered (General Oceanics flowmeters) nets were towed at 1 to $1.5 \mathrm{~m} \mathrm{~s}^{-1}$ for $10 \mathrm{~min}$ each, resulting in $\sim 400$ or $\sim 800 \mathrm{~m}^{3}$ sampling volumes for the neuston and subsurface nets, respectively. The total multiple-net tow duration was $<40 \mathrm{~min}$, and once on deck the samples were immediately preserved in $5 \%$ formalin in seawater to reduce the effects of decomposition in the $27^{\circ} \mathrm{C}$ surface water. The nets were then rinsed, and a second (rinse-residue) sample was collected from each net.

Following completion of plankton net sampling, we deployed TUBSS (towed underwater biological sens- ing system; Sprules et al. 1992, Taggart et al. 1996, Rissik et al. 1997, Suthers et al. 2004) for 20 min tows $\left(1.5 \mathrm{~m} \mathrm{~s}^{-1}\right)$, undulating the instrument between 5 and $120 \mathrm{~m}$ depth. TUBSS consists of an Endeco V fin fitted with a Focal Technologies OPC, an Ocean Sensors OS100 CTD and a flowmeter, which transmitted the data to the ship by the conducting tow cable. The OPC counts and estimates the size of any optically refractive particles as they enter a $2 \times 22 \mathrm{~cm}$ sampling tunnel and interrupt a coherent light beam $(4 \times 20 \mathrm{~mm}$; light emitting diode [LED] array). A photodiode receiver records the change in light intensity $(\mathrm{mV})$, calibrated as digital size intervals between 1 and $4096 \mathrm{mV}$ that correspond to sizes between 75 and $9000 \mu \mathrm{m}$ equivalent spherical diameter (ESD; Herman 1988, Sprules et al. 1992, Beaulieu et al. 1999). We re-classified the 4096 digital size classes to 64 size bins based on the integer value of the square root of the digital size class (due to initial size classification by particle-projected area). In practice the sampling resolution is restricted to between digital size classes 7 and 442 (Bins 3 to 21, 250 to $2500 \mu \mathrm{m} \mathrm{ESD;}$ Table 1). The effects of water turbidity, colour, chlorophyll and other particles <250 $\mu \mathrm{m}$ ESD are partially and automatically compensated by increasing the LED output, which is recorded as light attenuation $(\mathrm{mV})$. All data were collected at $0.5 \mathrm{~Hz}$; thus, sampling 11 to $15 \mathrm{l} \mathrm{s}^{-1}$ at 2.5 knots provided a vertical resolution of $1 \mathrm{~m}$ and a horizontal resolution of $2.5 \mathrm{~m}$. The dominant taxa of zooplankton from the plankton tows and their sizes (ESD) are reported in Rissik et al. (1997) and summarised here in Table 1.

Daytime sampling. On the 20 to 21 February we collected replicate daytime samples with the subsurface net at Stns E2 and N2. As no fish and few zooplankton were collected in the neuston, we did not deploy the neuston net. Multiple opening-closing net samples were collected in the 170 to 130,130 to 90 and 90 to $50 \mathrm{~m}$ depth strata, referred to hereafter as the 150, 110 and $70 \mathrm{~m}$ daytime depth bins, respectively.

We did not deploy the TUBSS at these daytime stations as above; instead we undulated the instrument between 5 and $120 \mathrm{~m}$ depth along 3 extended (5 to $24 \mathrm{~km}$ ) transects (I, II and III, Fig. 1) that intersected the net sampling stations. Navigational data recorded simultaneously from the vessel's GPS stream were merged with the OPC data stream $(<5 \%$ interpolation required). File management required data interruption $(<2 \mathrm{~min})$ at 25 to $35 \mathrm{~min}$ intervals.

Laboratory analysis. In the laboratory, the samples were sieved and rinsed and all larval and pelagic juvenile fish were sorted and identified to the lowest possible taxon using the keys of Leis \& Rennis (1983), Leis \& Trnski (1989), Moser et al. (1984) and Ozawa (1986). Due to time constraints only 2 replicate nights of each transect were sorted. 
Table 1. List of size classes used in the analyses and corresponding geometric mean equivalent spherical diameter (ESD), and the calculated biomass of a particle in each class. The dominant taxa are summarised from Rissik et al. (1997). Larval fish were removed from the samples before this analysis, but would occur in the $>2159 \mu \mathrm{m}$ ESD classes

\begin{tabular}{|c|c|c|}
\hline $\begin{array}{l}\text { ESD } \\
(\mu \mathrm{m})\end{array}$ & $\begin{array}{l}\text { Biomass } \\
(\mathrm{mg})\end{array}$ & Dominant taxa \\
\hline 318 & 0.017 & Invertebrate eggs \\
\hline 425 & 0.040 & $\begin{array}{l}\text { Copepods, larvae of mysids, cirripedes, } \\
\text { bryozoans }\end{array}$ \\
\hline 535 & 0.080 & $\begin{array}{l}\text { Mysids, copepods, cirripede, bryozoan } \\
\text { larvae }\end{array}$ \\
\hline 648 & 0.143 & Copepods, ostracods \\
\hline 764 & 0.234 & Copepods, ostracods \\
\hline 883 & 0.361 & Copepods, ostracods, mysids \\
\hline 1003 & 0.528 & Copepods, mysids, ostracods \\
\hline 1125 & 0.746 & Copepods, mysids \\
\hline 1249 & 1.020 & Copepods, mysids, chaetognaths \\
\hline 1375 & 1.361 & $\begin{array}{l}\text { Copepods, chaetognaths, mysids, } \\
\text { hyperids }\end{array}$ \\
\hline 1502 & 1.774 & $\begin{array}{l}\text { Copepods, chaetognaths, hyperids, } \\
\text { mysids }\end{array}$ \\
\hline 1631 & 2.272 & Copepods, hyperids, mysids \\
\hline 1761 & 2.859 & Copepods, mysids, chaetognaths \\
\hline 1893 & 3.552 & Copepods, chaetognaths, hyperids \\
\hline 2025 & 4.348 & Copepods, mysids, fish eggs, Lucifer \\
\hline 2159 & 5.269 & Mysids, Lucifer \\
\hline 2293 & 6.313 & Fish eggs, mysids, Lucifer \\
\hline 2429 & 7.504 & Fish eggs, mysids, Lucifer \\
\hline 2566 & 8.846 & Fish eggs, mysids, Lucifer \\
\hline
\end{tabular}

The OPC particle counts were converted to biomass ( $\mathrm{mg} \mathrm{m}^{-3}$, see below) and were depth binned to correspond with the nighttime net tows (105 to 75,75 to 45 , 45 to 15 and 5 to $10 \mathrm{~m}$ for the 'neuston'). Occasionally the TUBSS attained a 5th depth stratum at $120 \mathrm{~m}$. Where possible these size data were included graphically, but were not included in the analysis.

The biomass of each size class was determined by multiplying its abundance by its volume using its geometric mean ESD (mm, Table 1). This biomass calculation assumes that the volume of particles is adequately represented by a sphere, and that the volume has a specific gravity of 1 . Data were normalised (dividing the biomass by the size interval), and the average NBSS for each depth interval was calculated. We then determined the NBSS slope and intercept using least squares regression (Model 1). Rodriguez \& Mullin (1986b) report negligible differences among Model 1 and 2 regression parameters when size estimation incurs error. Some of the larger size classes had zero abundance and were deleted from the regression; we justifiably assume these size classes are undersampled given our sampling-volume resolution.
In addition to the NBSS, the size frequency of particles can be described by a Pareto distribution (Vidondo et al. 1997, Cavender-Bares et al. 2001). The Pareto distribution has a probability density function (pdf) defined as:

$$
\operatorname{pdf}(s)=c k^{c} s^{-(c+1)}
$$

where $s$ is the size of the particle (such as the weight class, $w$ ), and $c$ and $k$ are the distribution's shape and scale parameters, respectively (Vidondo et al. 1997). The main advantage of the Pareto distribution in this application is the insensitivity of analysis to the presence of the zero bin readings, a problem for larger size classes given the finite volumes sampled. An efficient estimator of $-C$ is the slope of the logarithm of the probability that a particle of random volume $W$ will exceed a size $w, \log _{10} \operatorname{Prob}(W \geq W)$, against $\log _{10} w$. The slope of the NBSS is an unbiased, although inefficient estimator of $-C$ (Vidondo et al. 1997). As a result, within the limitations of our data, and their conformity to the Pareto distribution, the slope of the NBSS should approximately equal the slope of $\log _{10} \operatorname{Prob}(W \geq W)$ regressed against $\log _{10} \mathrm{~W}$.

After confirming homogeneity of variance, the slope coefficients and larval fish abundance and diversity were compared in a 3-factor fully orthogonal ANOVA, followed by Student-Newman-Keuls post hoc comparisons. The Anguilliformes and other families representing $<0.01 \%$ of the total abundance were omitted from all analyses. The larval fish community was assessed using cluster analysis and non-metric multidimensional scaling (MDS) of the station-averaged data by means of a Bray-Curtis similarity matrix of $\log _{n}(x+1)$ transformed data. An identical MDS of the NBSS used just the normalised data.

The 3 daytime transects of TUBSS data were smoothed using a moving, 9-point, centred, weighted cosine filter (weights: $-0.041,-0.01,0.119,0.267,0.33$; Legendre \& Legendre 1998). Small negative abundances of the rare, larger particles (>1003 $\mu \mathrm{m}$ ESD) were generated by this filter, where there were occasional series of consecutive zeros; these were reverted to zero. A principal component analysis grouped the 18 size classes into small (318 to $883 \mu \mathrm{m}$ ESD) and large (>1002 $\mu \mathrm{m}$ ESD; Table 1). Contour sections of light attenuation and small zooplankton abundance along each of the 3 transects were obtained by Krigging using Surfer (Golden Software). We generated a gridded data set that approximated the vertical and horizontal sampling resolution, using a quadrat search radius of 2 to 3 nodes in horizontal and vertical dimensions, 24 data per gridding node and blanking where $<12$ data occurred within the search radius. The grid was then matrix smoothed with a double weight on the central node and a doubling of the grid resolution. 


\section{RESULTS}

\section{Daytime OPC transects}

Along Transect I (Fig. 1), from the free stream westwards to Stn N2, we detected a core of increased light attenuation at 50 to $90 \mathrm{~m}$ depth that was $17 \mathrm{~km}$ north and downstream of the reef (Fig. 2a). A thermocline was evident at 40 to $50 \mathrm{~m}$, at around $25^{\circ} \mathrm{C}$ (Fig. $2 \mathrm{~b}$ ). There was a similar increase in the biomass of small zooplankton at 50 to $90 \mathrm{~m}$, from 50 to $100 \mathrm{mg} \mathrm{m}^{-3}$ in the free stream to 150 to $250 \mathrm{mg} \mathrm{m}^{-3}$ around Stn N2 (Fig. 2b). This 'core' of enhanced biomass was apparent along Transect II, which extended from Cato Bank (up to $450 \mathrm{mg} \mathrm{m}^{-3}$ ) and north to Stn N1 (150 to $200 \mathrm{mg}$ $\mathrm{m}^{-3}$; Fig. 2c). Transect III confirmed the generally low zooplankton biomass (<100 $\mathrm{mg} \mathrm{m}^{-3}$; Fig. 2d) throughout the water column in the free stream east of Cato.

\section{Night/Day zooplankton biomass spectra}

The average normalised zooplankton biomass spectrum over the 18 size bins between 318 and $2500 \mu \mathrm{m}$ ESD, for the 6 stations, 4 upper depth intervals and 3 replicate nights $(\mathrm{n}=72)$ was: $y=-1.0534 \times \mathrm{ESD}-$ 1.7076 (average $r^{2}=0.95$ ). Inspection of the residuals revealed no non-linear trend. The intercept (at $10^{\circ} \mathrm{mg}$ ) was highly correlated with the slope ( $\mathrm{r}=0.91)$, such that at $1 \mathrm{mg}$ biomass, a steep slope (less than -1.1) had less normalised biomass than a shallow slope (greater than -0.9).

Fig. 3 displays the observed particle size distributions from the 90 deployments $\left(5\right.$ depths $\times 3$ stations $\mathrm{d}^{-1}$ $\times 6 \mathrm{~d})$ as the NBSS. Within each panel of Fig. 3 , the slope of the NBSS and the equivalent measure of the Pareto distribution are provided. The average NBSS slope over all 90 deployments around Cato Reef was -1.002 ( $\mathrm{SE}=0.013$, data ranging from -1.31 to -0.49 ; Fig. 3). The average intercept was -1.611 ( $\mathrm{SE}=0.045$, data ranging from -2.53 to 0.16 ). More variance in the NBSS occurred within the $120 \mathrm{~m}$ depth bin near the maximum depth reached by the TUBSS, when insufficient volume was sampled, resulting in an underestimation of the larger particles. The Pareto shape parameter $(-c)$ was highly correlated with the NBSS slope $(\mathrm{r}=0.90)$.

\section{Relationships of the NBSS slope}

The NBSS slope was significantly steeper near the thermocline at 30 or $60 \mathrm{~m}$ depth, than at $90 \mathrm{~m}$, which was greater than near the surface (overall $\mathrm{SE}=0.02$; Fig. 4, Table 2). The slopes within the wake at Stns N1 and N2 were significantly steeper than at the other 4 stations. There was significant correlation between the slope and light attenuation (material $<250 \mu \mathrm{m}$ ESD resolution of the OPC), such that across all stations and depths, steeper slopes were associated with greater light attenuation ( $\mathrm{r}=-0.43, \mathrm{p}<0.01$; Fig. 5) and more biomass of small zooplankton (Bins 3 to $8, \mathrm{r}=-0.28$ ).

\section{a) Light attenuation}

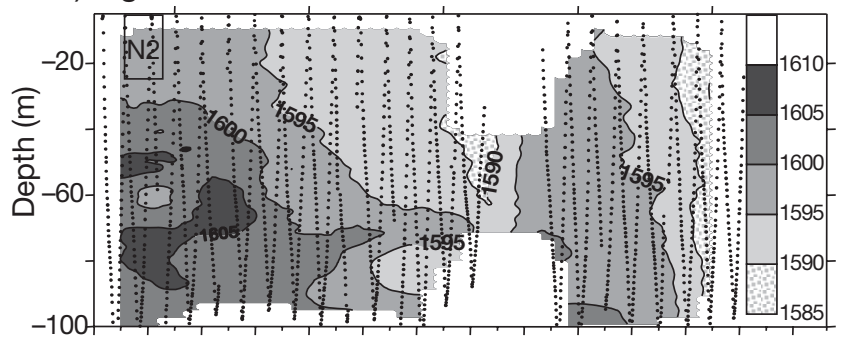

b) Small zooplankton

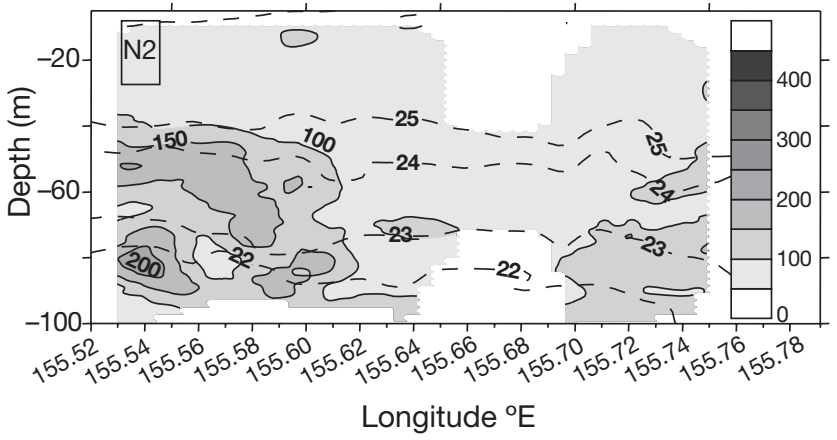

c) Sm. zooplankton

d) Small zooplankton

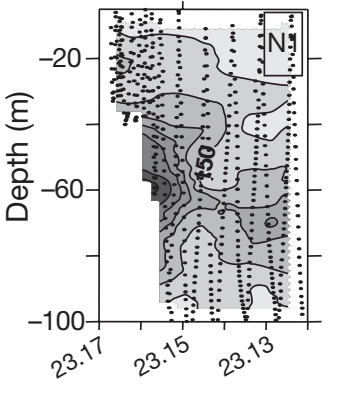

Latitude ${ }^{\circ} \mathrm{S}$

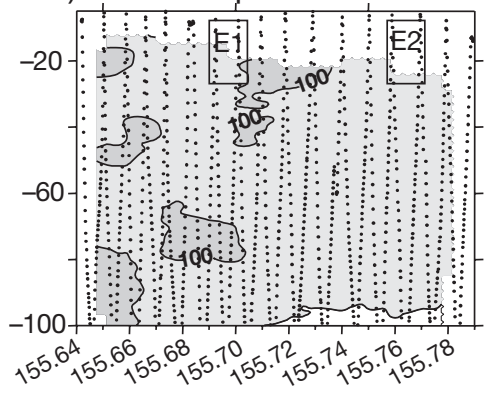

Longitude ${ }^{\circ} \mathrm{E}$

Fig. 2. Daytime vertical section plots of: (a) distribution of the optical plankton counter (OPC) light attenuation $(\mathrm{mV}$, corresponding to material $<250 \mu \mathrm{m}$ equivalent spherical diameter [ESD] resolution of the OPC, including phytoplankton) along the $24 \mathrm{~km}$ Transect I from the free stream to Stn N2; (b) the corresponding distribution of small zooplankton biomass of 318 to $883 \mu \mathrm{m}$ ESD, the dashed lines represent isotherms $\left({ }^{\circ} \mathrm{C}\right)$ (c) distribution of small zooplankton biomass along the $5.4 \mathrm{~km}$ Transect II, north from Cato Bank to Stn N1; and (d) the distribution of small (sm.) zooplankton biomass along the $15.4 \mathrm{~km}$ Transect III, from the edge of Cato Reef (off Hutchison Rock) to Stns E1 and E2. Locations of the Stns N1, N2, E1 and E2 are indicated, where daytime data were selected for comparison with the nighttime spectra 

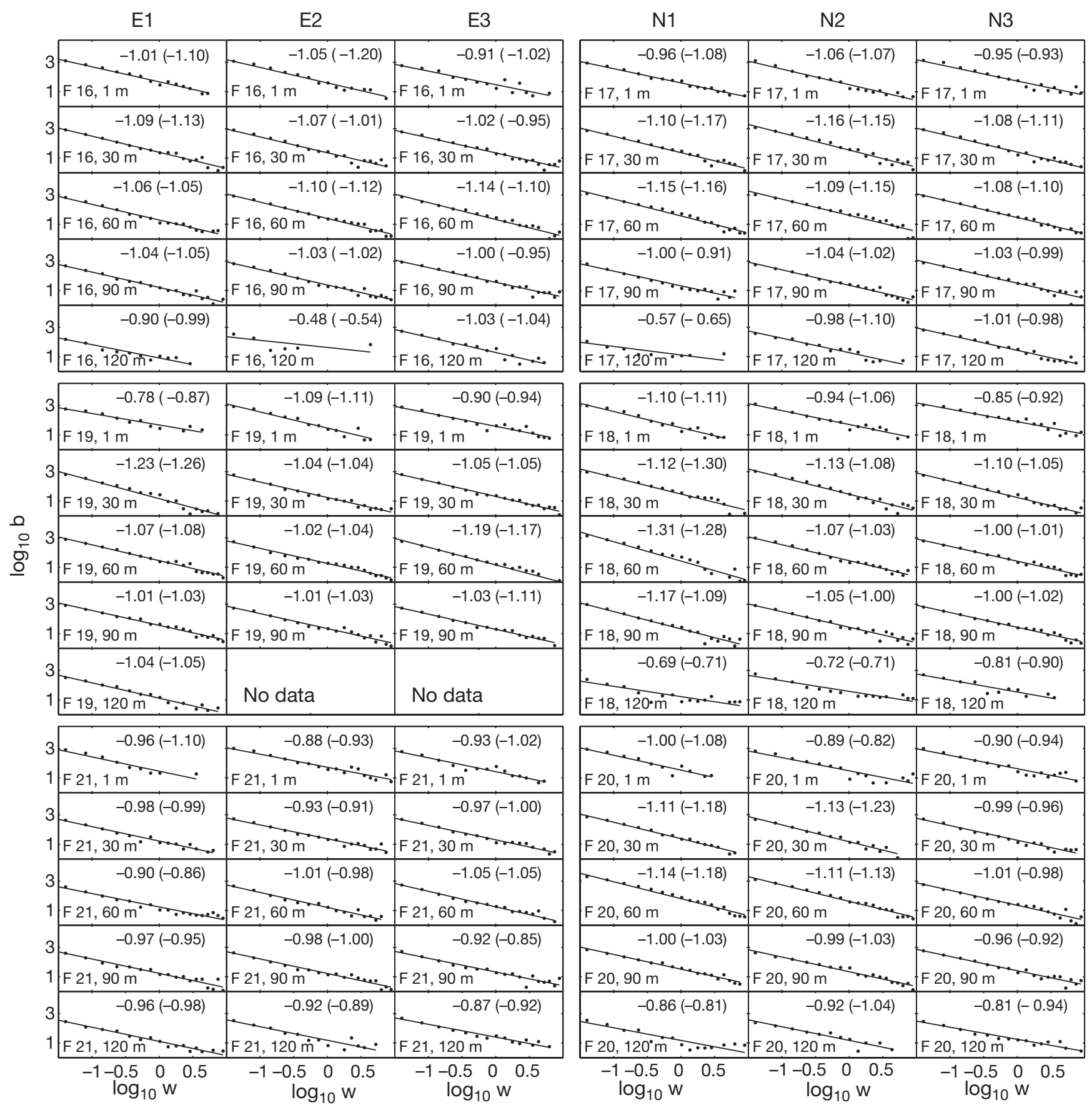

Fig. 3. $\log _{10}$ normalised biomass size spectra (NBSS) showing the normalised biomass $\left(\mathrm{mg} \mathrm{mm}^{-3} / \Delta\right.$ volume) as a function of size categories (from 0.02 to 8.85 mg; Table 1) from Stns E1, E2 and E3 on 16, 19 and 21 February (F16, F19 and F21) and Stns N1, N2 and N3 on 17, 18 and 20 February (F17, F18 and F20). Size distributions were measured at 1, 30,60 and 90 m depth intervals, and when possible $120 \mathrm{~m}$. The line through the measurements is a least squares regression, with its slope given above the graph. The bracketed value is the Pareto distribution shape parameter $-C$, which is highly correlated with the slope of the NBSS

There was no significant correlation between the NBSS slope and total zooplankton biomass (318 to $2566 \mu \mathrm{m}$ ESD biomass, Stns E1, E2, N1, N2).

There was no significant difference among the NBSS slopes between day and night at Stns E1/E2 and N1/N2, with similar results for the effects of depth and transect (Table 3). There was a significant difference in the total biomass of zooplankton between the day and night (ANOVA, $\mathrm{p}<0.001,157$ versus $207 \mathrm{mg} \mathrm{m}^{-3}, \mathrm{SE}=$ 12; Fig. 6), with a significant transect effect $(\mathrm{N}>\mathrm{E})$. However, the effect of depth was not statistically significant, as there were inconsistent nighttime effects. As 


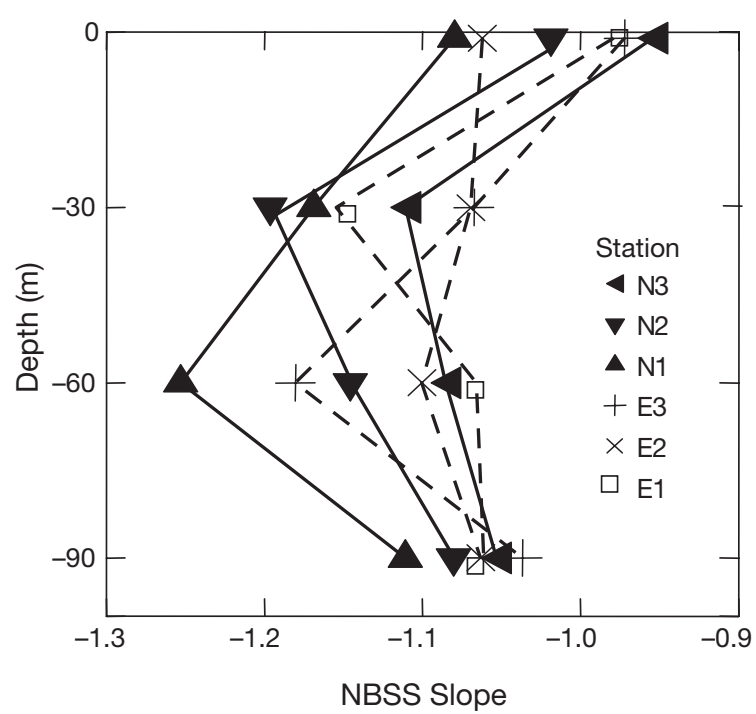

Fig. 4. Comparison among stations and depths of the mean NBSS slopes from the OPC-derived biomass size-frequency distributions; $\mathrm{n}=3$ slopes (each from separate nights) per plotted point. SE for comparison $=0.02$, approximately the symbol size. ANOVA comparison in Table 2. Slopes at Stn N1 $=\mathrm{N} 2>\mathrm{N} 3, \mathrm{E} 1, \mathrm{E} 2, \mathrm{E} 3$, and slopes at net depths $30 \mathrm{~m}=60 \mathrm{~m}>$

$90 \mathrm{~m}>$ surface, Student-Newman-Keuls post hoc tests

for the night, there was no significant correlation between the NBSS slope and total zooplankton biomass.

\section{Larval fish and zooplankton size community}

Over 16000 larval and pelagic juvenile fish from 58 families were collected from the 48 nighttime neuston and subsurface nets (Table 4 ), averaging nearly 0.5 larvae $\mathrm{m}^{-3}$. Over $50 \%$ of the catch was myctophids, and another $30 \%$ was gonostomatids. The myctophids were mostly black juveniles between 8 and $37 \mathrm{~mm}$ standard length and between 3.5 and $52 \mathrm{mg}$ dry weight (average $=15.2 \mathrm{~mm}$ and $8 \mathrm{mg}, \mathrm{n}=440$ and 270 ,

Table 2. ANOVA table for comparison of the log-normalised slopes of the zooplankton biomass spectrum on 3 replicate nights around Cato Reef (E: east; N: north). Factors in bold are significant at $\mathrm{p}<0.05$ (see Fig. 4)

\begin{tabular}{|lcccc|}
\hline Source & df & MS & \multicolumn{1}{c|}{$F$} & $\mathrm{p}$ \\
\hline Transect (E, N) & 1 & 0.025 & 5.17 & $\mathbf{0 . 0 3}$ \\
Station $(\mathbf{1}, \mathbf{2}, \mathbf{3 )}$ & 2 & 0.017 & 3.50 & $\mathbf{0 . 0 4}$ \\
Depth $(\mathbf{1}, \mathbf{3 0}, \mathbf{6 0}, \mathbf{9 0} \mathbf{~ m )}$ & 3 & 0.063 & 13.20 & $<\mathbf{0 . 0 0 1}$ \\
Transect $\times$ Station & 2 & 0.016 & 3.26 & $\mathbf{0 . 0 5}$ \\
Transect $\times$ Depth & 3 & 0.002 & 0.42 & 0.74 \\
Station $\times$ Depth & 6 & 0.002 & 0.46 & 0.83 \\
Transect $\times$ Station $\times$ Depth & 6 & 0.010 & 2.03 & 0.08 \\
Residual & 48 & 0.005 & & \\
Total & 71 & & & \\
\hline
\end{tabular}

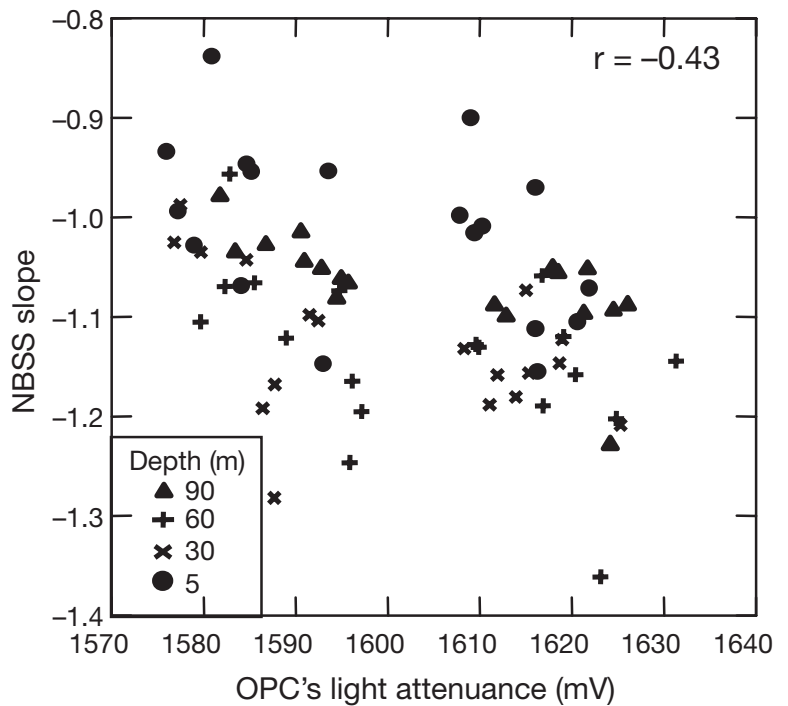

Fig. 5. Scatterplot of the NBSS slopes on the OPC's light attenuance signal $(\mathrm{mV}$, data to the left and right of 1600 are from the $\mathrm{E}$ and $\mathrm{N}$ transects, respectively). The significant correlation implies the NBSS slope is driven by the small and unresolved particles (i.e. light attenuance) and not the large particles or total biomass

respectively). Unidentified fish (fragments or abraided individuals) comprised $1.2 \%$ of the total catch. Total larval abundance was significantly influenced only by depth and not by the presence of the wake (Table 5). There were significantly more fish in the $30 \mathrm{~m}$ depth bin than in the $60 \mathrm{~m}$ bin, which had more than the neuston, or in the $90 \mathrm{~m}$ depth bin collections (Fig. 7a). There was no effect of any factor on the ShannonWiener diversity index (Table 5, overall average index = 1.55). We caught 254 larvae from 12 reef-associated families (Williams et al. 1988), based on families that constituted $>0.012 \%$ of the total catch. Other families (Table 4) that may be reef associated (e.g. Antenn-

Table 3. ANOVA table for comparison of the log-normalised slopes of the zooplankton biomass spectrum between day and night at Stns E1/E2 and N1/N2, around Cato Reef (E: east; N: north). Stns E1/E2 and N1/N2 were used as replicates. Factors in bold are significant at $\mathrm{p}<0.05$. Note that there is no significant difference between day (D) and night (N)

\begin{tabular}{|lccrc|}
\hline Source & df & MS & \multicolumn{1}{c|}{$F$} & p \\
\hline D/N (E, N) & 1 & 0.0032 & 1.77 & 0.20 \\
Transect (E, N) & 1 & 0.0253 & 13.97 & $\mathbf{0 . 0 0 2}$ \\
Depth (1, 30, 60, 90 m) & 3 & 0.0204 & 11.25 & $<\mathbf{0 . 0 0 1}$ \\
D/N $\times$ Transect & 1 & 0.0005 & 0.25 & 0.63 \\
D/N $\times$ Depth & 3 & 0.0008 & 0.43 & 0.74 \\
Transect $\times$ Depth & 3 & 0.0017 & 0.93 & 0.45 \\
D/N $\times$ Transect $\times$ Depth & 3 & 0.0006 & 0.31 & 0.82 \\
Residual & 16 & 0.0018 & & \\
Total & 31 & & & \\
\hline
\end{tabular}




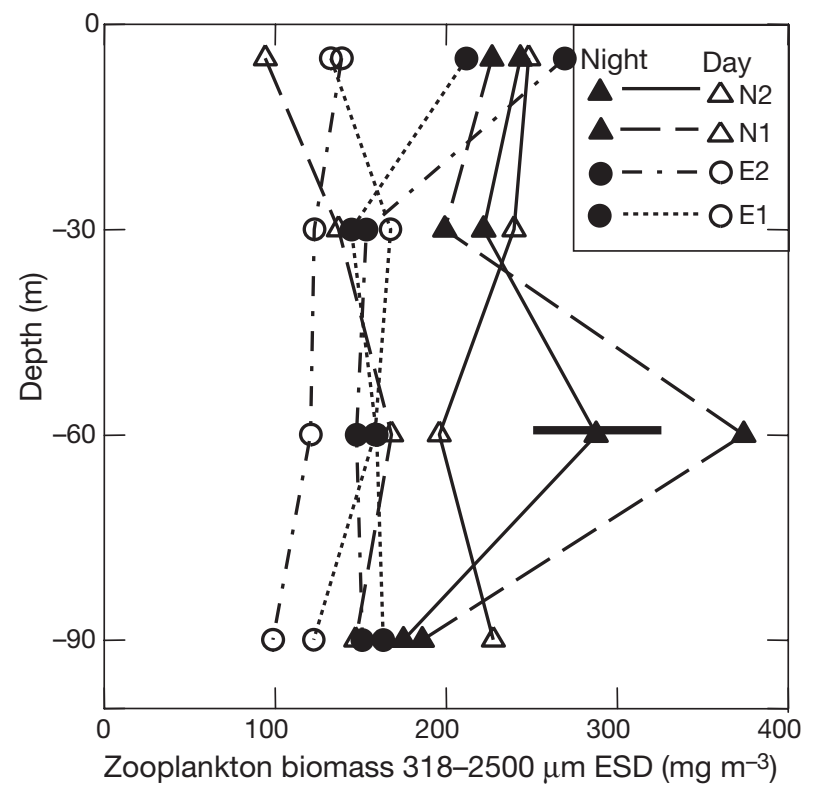

Fig. 6. Day versus night vertical distribution of zooplankton biomass recorded by the OPC at Stns E1, E2, N1 and N2. Daytime OPC data were selected from the vertical profiles near these stations shown in Fig. 2. The night distribution is the average for the 3 nights (horizontal bar indicates overall SE calculated by the ANOVA; Table 3). Despite the $30 \%$ increase in total biomass at night, the NBSS slopes were not significantly different

ariidae, Callionymidae) were rare. The Labridae (wrasses) composed nearly $50 \%$ of the reef fish. While we found a similar effect of depth, we also found more reef fish larvae at the eastern free-stream stations than within the wake (Table 5, Fig. 7b).

A cluster analysis of the Bray-Curtis similarity index of the station-depth averages revealed 3 broad groupings of families defined at the $15 \%$ similarity level (Fig. 8). One group contained 9 of the 12 reef fish families, and a second group included mostly the mesopelagic taxa, including the myctophids, gonostomatids, photichthyids and 2 reef fish families. A third group included the pelagic families of exocoetids, coryphaenids, scombrids and late pelagic juvenile ostraciids. An MDS of this similarity matrix (by sample) revealed 3 groupings related to depth: all the surface neuston samples with the pelagic families; nearly all the 30 and $60 \mathrm{~m}$ depth bin samples and the $90 \mathrm{~m}$ depth bin samples (Fig. 9). The one exception was the average $60 \mathrm{~m}$ sample from N1, which grouped with the $90 \mathrm{~m}$ samples, consistent with the mixing evident there (Fig. 2c). Importantly, there was no distinctive community of the northern wake region. The depth-related differences we determined were largely driven by the abundance of myctophids/gonostomatids in the 30 and $60 \mathrm{~m}$ depth bins and engraulids in the neuston. By omitting the neuston and $90 \mathrm{~m}$ depth data, as well as the myctophids and gonostomatids from the analysis, we determined a small but significant difference in the larval fish communities between the eastern and northern stations (ANOSIM, $\mathrm{R}=0.289, \mathrm{p}=0.007$ ); results were influenced by the relative abundance of paralepidids and labrids in the east and engraulids and bregmacerotids in the north. An identical MDS of the normalised zooplankton biomass does not show a similar pattern, except for the neuston tows (Fig. 9b).

There was no discrete grouping of the day and night samples in the MDS plot (not shown) derived from the Bray-Curtis similarity matrix based on the 8 abundant larval fish genera from the Myctophidae and Gonostomatidae at Stns E2 and N2 (Table 6). Regardless of day or night and E2 or N2 sampling, there was a core taxonomic group defined by the $60 \%$ similarity level, from the 30, 60, 70, 90 and $110 \mathrm{~m}$ depth bin collections. SIMPER analysis revealed that this group comprised the greatest abundance, particularly of Cyclothone
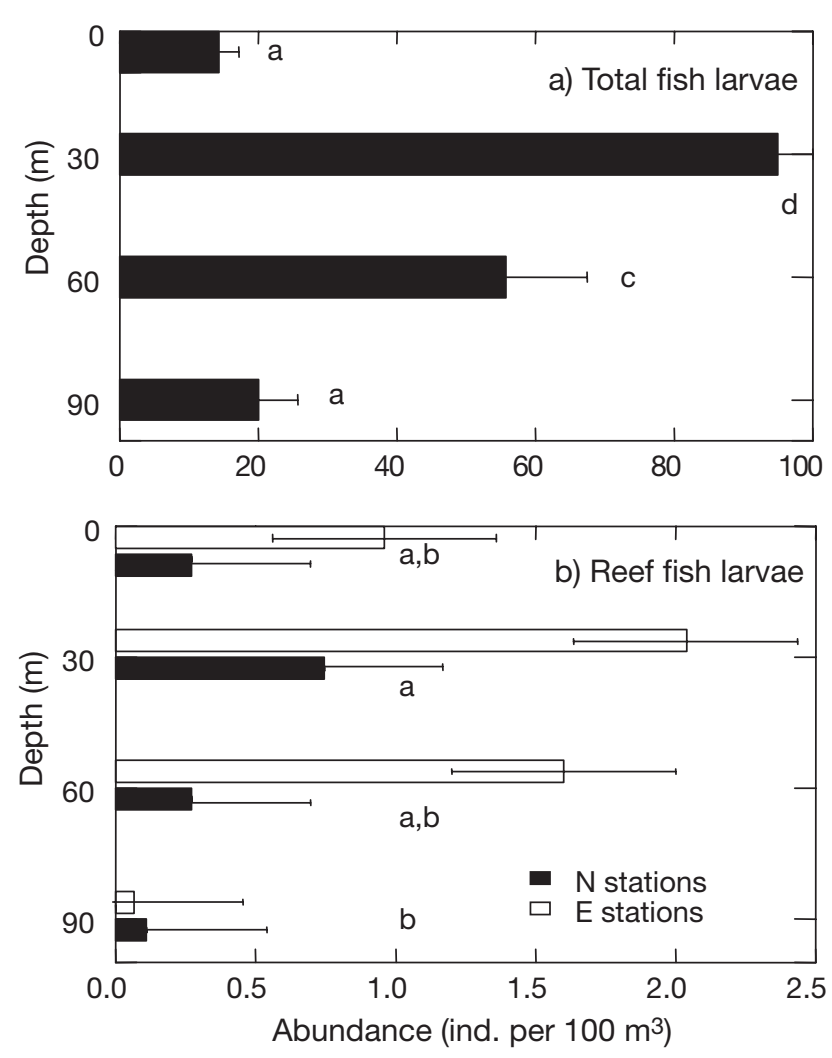

Fig. 7. (a) Average total numbers of larval fish with respect to the significant effect of net depth (columns with different letters are significantly different, ANOVA in Table 5); (b) average numbers of reef fish larvae with respect to the significant effects of net depth and transect (columns with different letters are significantly different, ANOVA in Table 5) 
Table 4. List of orders and families and total numbers of fish larvae/pelagic juveniles caught around Cato Reef in February 1993, percentage composition and, where identification was possible, list of dominant genera (or subfamilies)

\begin{tabular}{|c|c|c|c|c|}
\hline Order & Family & Dominant genera or subfamilies & Total & Percentage \\
\hline Anguilliformes & \multicolumn{2}{|c|}{ (leptocephali) } & 45 & $<1$ \\
\hline Clupeiformes & $\begin{array}{l}\text { Clupeidae } \\
\text { Engraulidae }\end{array}$ & Encrasiocholina & $\begin{array}{c}12 \\
636\end{array}$ & $\begin{array}{l}<1 \\
3.9\end{array}$ \\
\hline Stomiiformes & $\begin{array}{l}\text { Stomiidae } \\
\text { Chauliodontidae } \\
\text { Astronesthidae } \\
\text { Idiacanthidae } \\
\text { Malacosteidae } \\
\text { Melanostomiidae } \\
\text { Photichthyidae } \\
\text { Gonostomatidae } \\
\text { Sternoptythiidae }\end{array}$ & $\begin{array}{l}\text { Stomias } \\
\text { Chauliodontus } \\
\text { Idiacanthus } \\
\text { Vinciguerria } \\
\text { Cyclothone, Gonostoma, Diplophus }\end{array}$ & $\begin{array}{c}8 \\
7 \\
38 \\
11 \\
12 \\
81 \\
98 \\
5050 \\
6\end{array}$ & $\begin{array}{l}<1 \\
<1 \\
<1 \\
<1 \\
<1 \\
<1 \\
<1 \\
30.0 \\
<1\end{array}$ \\
\hline Aulopieformes & $\begin{array}{l}\text { Scopelarchidae } \\
\text { Notosudidae } \\
\text { Synodontidae } \\
\text { Paralepididae } \\
\text { Evermannellidae }\end{array}$ & $\begin{array}{l}\text { Synodus } \\
\text { Lestidiops, Studis,Lestidium, Paralepis, Stemnosudis } \\
\text { Evermannella, Odontonops }\end{array}$ & $\begin{array}{c}12 \\
23 \\
49 \\
357 \\
48\end{array}$ & $\begin{array}{l}<1 \\
<1 \\
<1 \\
2.1 \\
<1\end{array}$ \\
\hline Myctophieformes & Myctophidae & See Table 6 & 9403 & 55.0 \\
\hline Gadiformes & Bregmacerotidae & Bregmaceros & 129 & $<1$ \\
\hline Ophidiiformes & $\begin{array}{l}\text { Ophidiidae } \\
\text { Carapdidae }\end{array}$ & & $\begin{array}{l}4 \\
3\end{array}$ & $\begin{array}{l}<1 \\
<1\end{array}$ \\
\hline Lophiiformes & Antennariidae & & 32 & $<1$ \\
\hline Atheriniformes & $\begin{array}{l}\text { Exocoetidae } \\
\text { Hemiramphidae }\end{array}$ & & $\begin{array}{l}4 \\
2\end{array}$ & $\begin{array}{l}<1 \\
<1\end{array}$ \\
\hline Lampridiformes & Trachipteridae & & 2 & $<1$ \\
\hline Beryciformes & Holocentridae & & 2 & $<1$ \\
\hline Syngnathiformes & Syngnathidae $^{a}$ & & 1 & $<1$ \\
\hline Scorpaeniformes & $\begin{array}{l}\text { Scorpaenidae } \\
\text { Platycephalidae }\end{array}$ & & $\begin{array}{l}9 \\
1\end{array}$ & $\begin{array}{l}<1 \\
<1\end{array}$ \\
\hline Perciformes & 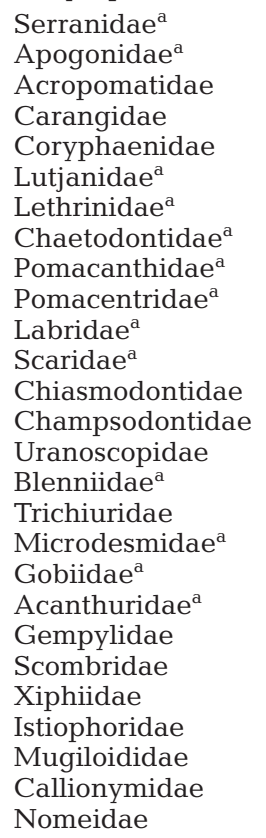 & $\begin{array}{l}\text { Grammistinae, Epinephelinae, Amphiinae } \\
\text { Apogon } \\
\text { Howella } \\
\text { Chaetodon } \\
\text { Centropyge } \\
\text { Calatomus } \\
\text { Naso } \\
\text { Katsuwomus, Scomber, Gymnosarda, Thunnus }\end{array}$ & $\begin{array}{c}5 \\
10 \\
58 \\
7 \\
11 \\
10 \\
4 \\
2 \\
5 \\
6 \\
136 \\
36 \\
73 \\
11 \\
5 \\
2 \\
3 \\
1 \\
2 \\
9 \\
110 \\
21 \\
1 \\
1 \\
1 \\
29 \\
1\end{array}$ & $\begin{array}{l}<1 \\
<1 \\
<1 \\
<1 \\
<1 \\
<1 \\
<1 \\
<1 \\
<1 \\
<1 \\
<1 \\
<1 \\
<1 \\
<1 \\
<1 \\
<1 \\
<1 \\
<1 \\
<1 \\
<1 \\
<1 \\
<1 \\
<1 \\
<1 \\
<1 \\
<1 \\
<1 \\
<1\end{array}$ \\
\hline Plleuronectiformes & $\begin{array}{l}\text { Bothidae } \\
\text { Cynoglossidae }\end{array}$ & & $\begin{array}{c}96 \\
1\end{array}$ & $\begin{array}{l}<1 \\
<1\end{array}$ \\
\hline Teraodontiformes & $\begin{array}{l}\text { Balistidae }^{\mathrm{a}} \\
\text { Ostraciidae }^{\mathrm{a}} \\
\text { Tetraodontidae }^{\mathrm{a}}\end{array}$ & & $\begin{array}{c}1 \\
17 \\
7\end{array}$ & $\begin{array}{l}<1 \\
<1 \\
<1\end{array}$ \\
\hline $\begin{array}{l}\text { Unidentified } \\
\text { Overall total }\end{array}$ & & & $\begin{array}{c}196 \\
16356\end{array}$ & 1.2 \\
\hline
\end{tabular}


Table 5. ANOVA table for comparison of total number of larval fish $\left(100 \mathrm{~m}^{-3}\right.$; Fig. $\left.7 \mathrm{a}\right)$, the Shannon-Wiener diversity index $\left(H^{\prime} \log _{2}\right)$ and the abundance of reef-associated taxa $\left(100 \mathrm{~m}^{-3}\right.$; Fig. $\left.7 \mathrm{~b}\right)$ on 2 replicate nights around Cato Reef (E: east; N: north). Factors in bold are significant at $p<0.05$

\begin{tabular}{|c|c|c|c|c|c|c|c|c|c|c|}
\hline \multirow[t]{2}{*}{ Source } & \multirow[t]{2}{*}{$\mathrm{df}$} & \multicolumn{3}{|c|}{ Total larval fish } & \multicolumn{3}{|c|}{ Diversity index } & \multicolumn{3}{|c|}{ Reef taxa abundance } \\
\hline & & MS & $F$ & $\mathrm{p}$ & MS & $F$ & $\mathrm{p}$ & MS & $F$ & $\mathrm{p}$ \\
\hline Transect $(E, N)$ & 1 & 208.9 & 0.21 & 0.7 & 0.42 & 1.55 & 0.2 & 8.04 & 8.30 & 0.01 \\
\hline Station $(1,2,3)$ & 2 & 569.7 & 0.58 & 0.6 & 0.21 & 0.79 & 0.5 & 0.17 & 0.18 & 0.8 \\
\hline Depth $(1,30,60,90 \mathrm{~m})$ & 3 & 16686.2 & 17.11 & $<0.001$ & 0.43 & 1.61 & 0.2 & 3.62 & 3.74 & 0.02 \\
\hline Transect $\times$ Station & 2 & 2026.1 & 2.08 & 0.2 & 0.06 & 0.22 & 0.8 & 0.47 & 0.49 & 0.6 \\
\hline Transect $\times$ Depth & 3 & 96.3 & 0.10 & 0.9 & 0.24 & 0.91 & 0.5 & 1.25 & 1.29 & 0.3 \\
\hline Station $\times$ Depth & 6 & 1828.6 & 1.88 & 0.1 & 0.20 & 0.76 & 0.6 & 0.30 & 0.31 & 0.9 \\
\hline Transect $\times$ Station $\times$ Depth & 6 & 725.3 & 0.74 & 0.6 & 0.07 & 0.27 & 0.9 & 0.46 & 0.48 & 0.8 \\
\hline Residual & 24 & 975.0 & & & 0.27 & & & 0.96 & & \\
\hline Total & 47 & & & & & & & & & \\
\hline
\end{tabular}

and Diaphus (and less abundance of Myctophum and Lampanyctus), which characterised the nighttime neuston tows. Benthosema and Diogenichthys distinguished the daytime tows at E-150 m and N-110 m.

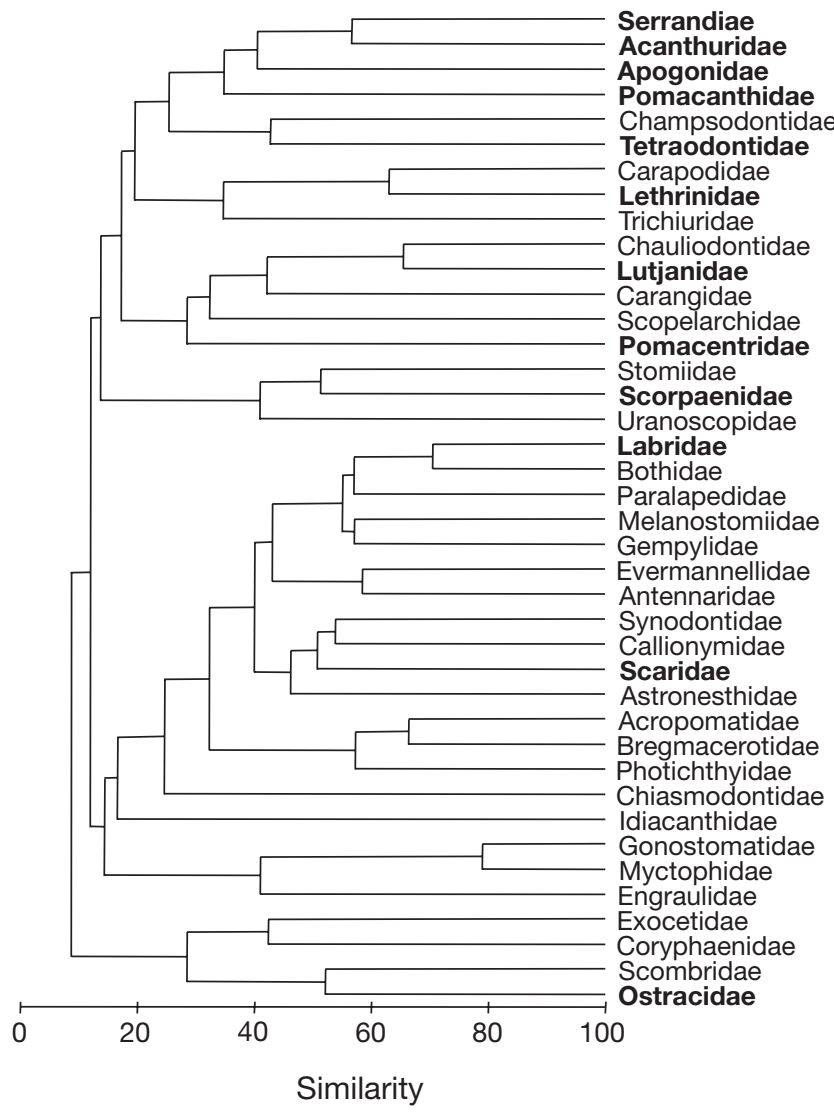

Fig. 8. Cluster diagram of the Bray-Curtis similarity matrix of 40 larval and pelagic juvenile fish families [mean abundance: $\ln (x+1)$ transform] caught around Cato Reef in February 1993. Reef-associated taxa (after Williams et al. 1988) are in bold and tend to be grouped together

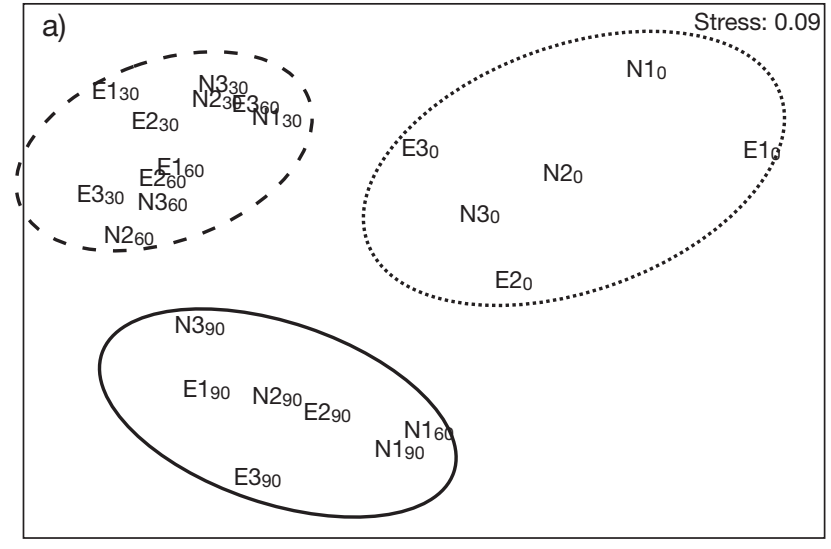

b)

Stress: 0.1

E10

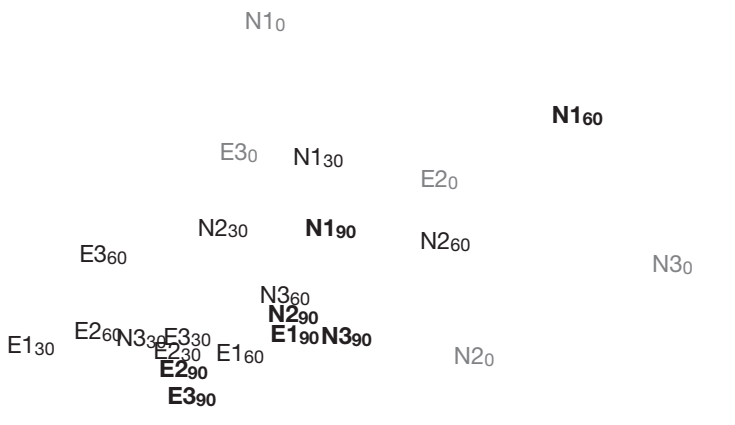

Fig. 9. (a) Multidimensional scaling (MDS) analysis plot of the Bray-Curtis similarity matrix of 6 stations $\times 4$ depths (0: surface; 30: at 15 to $45 \mathrm{~m} ; 60$ : at 45 to $75 \mathrm{~m} ; 90$ [solid line]: at 75 to $105 \mathrm{~m})$, derived from Fig. 8. Circles enclose those families grouped at the $50 \%$ similarity of the cluster dendrogram. (b) An identical MDS analysis plot of the Bray-Curtis similarity matrix of the averaged normalised zooplankton biomass. The $90 \mathrm{~m}$ depth grouping shown in (a) with a solid circle is bold in (b), while the neuston grouping shown with a dotted circle in (a) is grey in (b) 
Table 6. Myctophid and gonstomatid genera that could be identified, and their percentage abundance in the total catch of larval and pelagic juvenile fish

\begin{tabular}{|llrc|}
\hline Family & Genus & Total & Percentage \\
\hline Myctophidae & & 9109 & 55.7 \\
& Myctophum & 515 & 3.2 \\
& Symbolophorus & 574 & 3.5 \\
& Diogenichthys & 216 & 1.3 \\
& Lampanyctus & 487 & 3.0 \\
& Diaphus & 2561 & 15.7 \\
& Triphoturus & 144 & 0.9 \\
& Hygophum & 49 & 0.3 \\
& Benthosema & 111 & 0.7 \\
& Notolynchus & 6 & $<0.1$ \\
& Other & 4446 & 27.2 \\
Gonostomatidae & 4887 & 29.9 \\
& Cyclothone & 3063 & 18.7 \\
& Other & 1824 & 11.2 \\
\hline
\end{tabular}

The abundances of only the myctophids and gonostomatids were negatively correlated with the NBSS slope, such that we observed fewer larvae with shallower slopes (Fig. 10). There were 5 samples with very low fish abundance but steep slopes. There was no significant correlation with the NBSS intercept.

\section{DISCUSSION}

Despite a weak incident northward flow at Cato Reef, there was a strong and consistent response to the wake in the chlorophyll and zooplankton biomass (Suthers 1996, Rissik et al. 1997, Coutis \& Middleton 1999), but no detectable difference in the total abundance or community of larval fish (except the reef fish larvae, which as a group were less abundant in the island wake; see later). The daytime vertical section plots of the small zooplankton biomass clearly showed high concentrations off the northern bank of Cato Reef, extending beyond Stn N2 (Transect II). An earlier analysis of the zooplankton composition (Rissik et al. 1997) did not indicate any difference in taxa between the wake and free stream; thus, our observations are not simply related to a plume of reef-associated zooplankton. We also found that the NBSS slopes were steeper near the thermocline $(-1.15$ compared to -1.05 at the surface) and near the subsurface chlorophyll maximum, where zooplankton biomass and production tend to be enhanced.

In contrast to some of our results described above, Rodriguez \& Mullin (1986b) report that in the NPCG the normalised spectra of zooplankton carbon were steeper near the surface (approximately -1.32) and significantly less at 40 to $100 \mathrm{~m}$ depth $(-1.13)$. They used bottle collections and a $183 \mu \mathrm{m}$ mesh plankton net to obtain 19 size classes produced by sieving
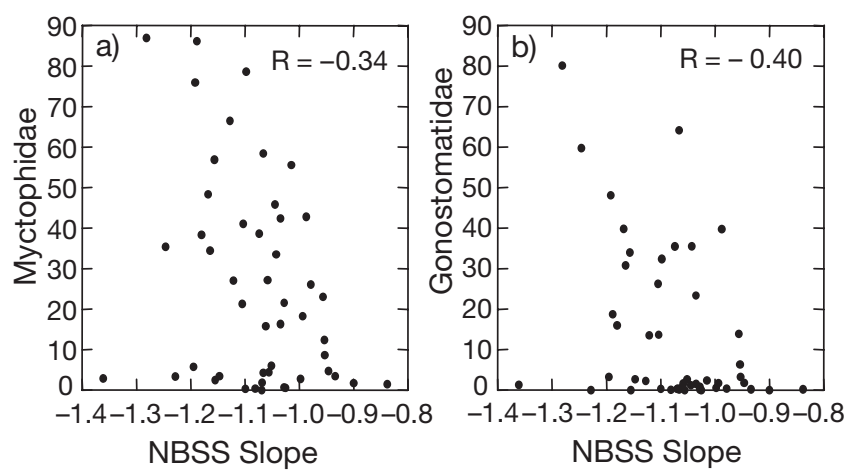

Fig. 10. Scatterplot of: (a) the concentration of myctophids and (b) the concentration of gonostomatids on the NBSS slope

using 10 to $4000 \mu \mathrm{m}$ mesh screens. The contrast may be driven by the steeper slopes characteristic of microzooplankton (<200 $\mu \mathrm{m}$ mesh). The same authors converted their biomass estimates to carbon because organic matter (C) rather than biomass is transferred across the biomass spectrum. We did not convert our data given the debatable nature of the appropriate conversion factors for small and large zooplankton (e.g. Woodd-Walker et al. 2000), as well as possible geographic differences.

We found the NBSS slopes to be significantly steeper within the island wake relative to the free stream, consistent with other indices of secondary production such as the enhanced gut fullness indices of myctophids at Stns N1 and N2 (Rissik \& Suthers 2000), and enhanced growth rates of the myctophid Diaphus kapalae at Stn N3 (Suthers 1996). Admittedly, the correlation among these indices with the NBSS slope was weak, in part due to the different scales that each measure represents.

The NBSS slope appears to be influenced by production of the smaller size fraction as it was highly correlated with light attenuation (chlorophyll and particles $<250 \mu \mathrm{m}$ ESD; Fig. 5), less so with the biomass of small zooplankton and not correlated with large zooplankton or total biomass. In other words, the zooplankton biomass at Cato Reef was relatively fixed among the larger size categories and fluctuated more among the smaller size categories. Remarkably, the slope did not vary significantly among nights nor between day and night (Fig. 6), despite a $30 \%$ increase in the nighttime zooplankton biomass. This implies that vertical migration (or gear avoidance) must occur similarly among all size classes measured. The day-to-night change in biomass was largely related to Stns N1 and N2, and yet the average NBSS slopes changed only from -1.14 to -1.13. In this day/night ANOVA comparison, our daytime sampling was unreplicated such that we had to combine the 2 inner stations on each transect as repli- 
cates (N1/N2 or E1/E2). Our day/night finding is similar to OPC-derived data from the California Current, in which no significant day/night difference was observed in zooplankton collected between 0 and $300 \mathrm{~m}$ depth (Huntley et al. 1995). The vertical distribution of the macrozooplankton slope from the NPCG ( $<100 \mathrm{~m}$; Rodriguez \& Mullin 1986b) showed a similar slope for day and night, but a smaller intercept for the day samples. Thus, there was similar overall diel vertical migration or gear avoidance across the size range. The summer size spectra of the NPCG were significantly different between day and night, due to vertical migration by the largest zooplankton (Rodriguez \& Mullin 1986b). In summary, the Coral Sea system appears to be in a steady state, as we observed no significant temporal variation in the biomass spectrum slope around Cato Reef, and some consistent spatial variation, thus conforming to a basic assumption of the biomass size spectrum approach (Heath 1995). We speculate that our findings may be due, in part, to the remarkable linearity of our spectra $\left(\mathrm{r}^{2}>0.94\right)$, which we believe to be a result of intense predation in a nutrient-limited ecosystem such as the Coral Sea. Nutrient limitation was evident in the nitrate and phosphorous concentrations at or below detectable limits in the upper $80 \mathrm{~m}\left(<0.5\right.$ and $<0.15 \mu \mathrm{mol} \mathrm{l}^{-1}$, respectively; Rissik et al. 1997). Other potential predators, apart from the predatory mesopelagic fishes (Rissik \& Suthers 2000), were the numerically dominant chaetognaths and mysids found throughout the size spectrum (Rissik et al. 1997). It would be interesting to see what the NBSS might look like in the oligotrophic South Pacific Gyre.

The size structure of the planktonic community was assessed using the NBSS, and summarised using the slopes therein along with the shape parameter of the Pareto distribution. The advantage of the Pareto distribution analysis is that it does not require particles to be binned into size classes. Unfortunately, we did not analyse the actual size of the particles, but only the size bin to which they were allocated. Nonetheless, we calculated the Pareto distribution because it is ideally suited to size-frequency data and avoids the problem of zero bin readings due to sampling of a finite volume. On the other hand, the Pareto statistic is not based on the fundamental predator-prey size relationships of the biomass size spectrum (Heath 1995). The Pareto is statistically rigorous, but was developed for a range of size-based phenomena and, unlike the NBSS, currently has no biological basis for plankton.

The correlation between $-C$ and the slope of the NBSS demonstrates a tendency for the slope of the NBSS to underestimate $-C$ for the less negative slopes (Fig. 3). This is expected given the removal of zero bins in our NBSS analysis. Zero bins occurred for the largest and most rare size classes, which was simply a result of the exponential decrease in abundance of the larger sizes in a finite volume. The removal of low readings elevates the relation, with a resultant overestimate of the NBSS slope (i.e. less negative). The slope coefficient between $-c$ and the NBSS slope for samples with non-zero bins is -1.1 . A 1:1 correspondence between $-C$ and the slope of NBSS should only be expected if the sampled size distribution is, in fact, well approximated by a Pareto distribution. As the true size distribution increasingly departs from the Pareto distribution, or as the sampling fails to reflect the true distribution, a 1:1 correspondence becomes less likely. In any case, the relationship between $-C$ and the NBSS slope is reasonably strong.

\section{Larval fish and zooplankton size community}

The total abundance of ichthyoplankton at night was greatest in the $30 \mathrm{~m}$ depth collections (range: 15 to $45 \mathrm{~m}$ ), above the 50 to $80 \mathrm{~m}$ depth of the thermocline region, which was also sampled, in part, within the $60 \mathrm{~m}$ depth bin. This pattern is typical of that found in the tropical ocean (Loeb 1979, Boehlert \& Mundy 1993, Röpke 1993) and presumably results from the prey distribution-particularly the higher production steep slope evident in the NBSS (Fig. 4). The concentration of ichthyoplankton in the neuston and at $90 \mathrm{~m}$ depth was $<1 / 3$ that found at mid-depth. The paucity of reefassociated taxa was remarkable, amounting to $<2 \%$ of the catch $\left(<0.008 \mathrm{~m}^{-3}\right)$, despite collections at stations nearest the reef being within $5 \mathrm{~km}$ of the lagoon and our sampling being during the summer's new moon, when reef fish either spawn or settle. The paucity of larval fish around Cato Reef was also remarkable when compared to a near-identical nighttime sampling regime near the coast $1 \mathrm{wk}$ earlier. The neuston net yielded 10-fold fewer larvae at Cato $\left(0.14 \mathrm{~m}^{-3}\right)$ compared to that around a coastal island $\left(1.40 \mathrm{~m}^{-3}\right)$ located near the $40 \mathrm{~m}$ isobath just $18 \mathrm{~km}$ off the mainland (Suthers et al. 2004); thus, ichthyoplankton abundance was, in general, relatively poor.

The wrasses were the major reef fish taxon, found principally on the eastern transect and not in the first MDS grouping that contained 9 of the 12 reefassociated taxa. The paucity of reef fish downstream of Cato indicates that the reef may act to remove larvae, rather than the expected increase in reef fish larvae downstream (e.g. Williams \& English 1992). The selective removal of reef-associated larvae possibly occurred through settlement, but particularly by zooplankton predation, as macrozooplankton was particularly abundant at Stn N1. We infer that the eddies of deep ocean islands could be a sink for reef larvae, 
rather than a favourable mechanism for larval retention and survival.

Over $80 \%$ of the catch was composed of mesopelagic taxa such as myctophids and gonostomatids, found in the 30 and $60 \mathrm{~m}$ depth bin collections. We did not observe any increase in abundance downstream of the reef, nor any significant variation in ichthyoplankton diversity. The MDS analysis did group the $60 \mathrm{~m}$ collections at Stn N1 with the 90 m collections (Fig. 9a), consistent with an uplift of deep biota within the wake nearest the island. Thus, the biota appear to act as a water-mass tracer (sensu Smith \& Suthers 1999). In contrast the MDS groupings of the normalised zooplankton biomass did not reflect the ichthyoplankton communities, nor the depth bins, except for the neuston. The second MDS of the abundant mesopelagic fishes grouped the shallow, mid-depth and deep samples together, regardless of being collected north or east of the island or during the day or night. This 'core' group was composed of the gonostomatids Diaphus, Myctophum and Lampanyctus at the $>60 \%$ similarity level (e.g. Röpke 1993). There appeared to be a daytime descent of the myctophids Benthosema and Diogenichthys, and complete avoidance of the daytime neuston, but otherwise, at the scale of our depth-stratified sampling, the diel vertical distributions were unremarkable. The lack of major differences in vertical distribution of mesopelagic larval and juvenile fish (apart from the neuston) is important in the design of future sampling programs.

The NBSS slope was negatively correlated with the abundance of myctophids and gonostomatids, such that a steeper slope was associated with greater myctophid and gonostomatid abundance. Both taxa were found to preferentially select the medium to large zooplankton prey (0.2 to $1.0 \mathrm{mg}$; Rissik \& Suthers 2000), and could exert top-down control of the zooplankton size spectrum, thus creating a steeper slope (Fig. 11). Typically, steeper slopes of the NBSS are associated with increased production from smaller zooplankton (bottom-up control). In fact, both increased production by small zooplankton, stimulated by the predators' excretion, and predation by large zooplankton may steepen the NBSS slope. It is also possible that the NBSS may become non-linear at the larger sizes in this study, around the 10 to $100 \mathrm{mg}$ sizes of larval fish that correspond to the 'domes' of the size-structured biomass observed in the Great Lakes (Sprules \& Goyke 1994). Further study of the 10 to $1000 \mathrm{mg}$ size range appears necessary, perhaps from combined plankton collections and acoustic (backscatter) data. It is interesting that the dominant prey of the vast yellow fin tuna resource (gonostomatids and myctophids; McPherson 1991) may also be the region's dominant zooplankton predators.

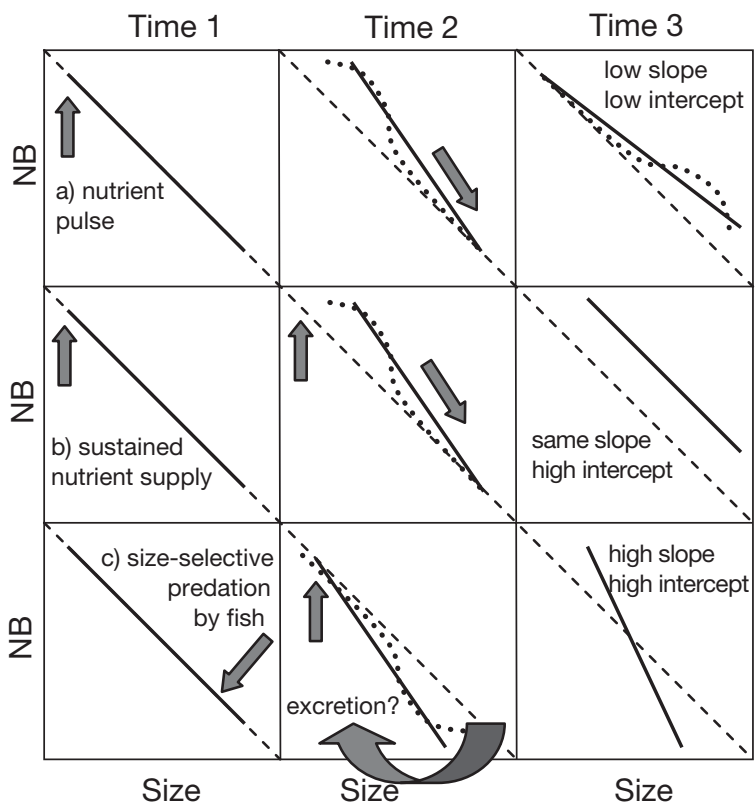

Fig. 11. Sketch of 3 possible bottom-up and top-down processes altering the -1 slope and intercept of the zooplankton NBSS around Cato Reef, during 3 time periods: (a) a nutrient pulse stimulates phytoplankton, increasing the (normalised) biomass concentration of small zooplankton particles, which is passed by predation to larger particles; (b) a sustained nutrient supply increases the biomass and intercept; (c) sizeselective predation by larval and juvenile fish could steepen the slope, and their excreted nutrients could increase the production of smaller particles. The NBSS is relatively linear for the zooplankton domain, but could become non-linear with biomass domes of planktivorous fish

Acknowledgements. We acknowledge the taxonomic coaching of Jeff Leis, Tom Trnski, Tony Miskiewicz and John Paxton of the Australian Museum, and our team of sorters: Matt Lockert, Peter Barnes and Ron Avery. We particularly thank the captain and crew of the 'Franklin' and the CSIRO scientific support staff for their professional support and genuine enthusiasm for the project. This study was funded by grants to I.M.S. from the Australian Research Council, the Department of Industry Science and Technology and Australian Geographic and to C.T.T. from the Canada Department of Fisheries and Oceans, Focal Technologies and the Natural Sciences and Engineering Research Council of Canada. The Department of Oceanography at Dalhousie University and the Bedford Institute of Oceanography provided the senior author with the resources to write up this work. Our patient anonymous reviewers suggested significant improvements.

\section{LITERATURE CITED}

Beaulieu SE, Mullin MM, Tang VT, Pyne SM, King AL, Twining BS (1999) Using an optical plankton counter to determine the size distributions of preserved zooplankton samples J Plankton Res 21:1939-1956

Boehlert GW, Mundy BC (1993) Ichthyoplankton assemblages at seamounts and oceanic islands. Bull Mar Sci 53: 336-361 
Boehlert GW, Watson W, Sun LC (1992) Horizontal and vertical distributions of larval fishes around an isolated oceanic island in the tropical Pacific. Deep-Sea Res 39:439-466

Cavender-Bares KK, Rinaldo A, Chisholm SW (2001) Microbial size spectra from natural and nutrient enriched ecosystems. Limnol Oceanogr 46:778-789

Coutis PF, Middleton JH (1999) Flow topography interaction in the vicinity of an isolated, deep ocean island. Deep-Sea Res 46:1633-1652

Cowen RK, Castro LR (1994) Relation of coral reef fish larval distributions to island scale circulation around Barbados, West Indies. Bull Mar Sci 54:228-244

Genin A, Boehlert GW (1985) Dynamics of temperature and chlorophyll structures above a seamount: an oceanic experiment. J Mar Res 43:907-924

Gilmartin M, Revelante N (1974) The 'island mass' effect on the phytoplankton and primary production of the Hawaiian islands. J Exp Mar Biol Ecol 16:181-204

Heath M (1995) Size spectrum dynamics and the planktonic ecosystem of Loch Linnhe. ICES J Mar Sci 52:627-642

Herman AW (1988) Simultaneous measurements of zooplankton and light attenuance with a new optical plankton counter. Cont Shelf Res 8:205-221

Heywood KJ, Barton ED, Simpson JH (1990) The effects of flow disturbance by an oceanic island. J Mar Res 48:55-73

Huntley ME, Zhou M, Nordhausen W (1995) Mesoscale distribution of zooplankton in the California Current in late spring, observed by optical plankton counter. J Mar Res 53:647-674

Kerr SR, Dickie LM (2001) The biomass spectrum. A predator-prey theory of aquatic production. Columbia University Press, New York

Legendre L, Legendre P (1998) Numerical ecology. Developments in environmental modeling, Vol 3. Elsevier, Amsterdam

Leis JM, Rennis D (1983) The larvae of Indo-Pacific coral reef fishes. University of New South Wales Press, Sydney

Leis J, Trnski T (1989) The larvae of Indo-Pacific shorefishes. University of New South Wales Press, Sydney

Loeb VL (1979) Vertical distribution and development of larval fishes in the North Pacific central gyre during summer. Fish Bull 77:777-793

McPherson GR (1991) A possible mechanism for the aggregation of yellowfin and bigeye tuna in the north-western Coral Sea. Queensland Department of Primary Industries Information Series No. AI 9013, Brisbane

Moore SK, Suthers IM (2006) Evaluation and correction of subresolved particles by the optical plankton counter in three Australian estuaries with pristine to highly modified catchments. J Geophys Res 111, C05S04, doi:10.1029/ 2005JC002920

Moser HG, Richards WJ, Cohen DM, Fahay MP, Kendall AW, Richardson SL (eds) (1984) Ontogeny and systematics of fishes. Spec. Publ. Am Soc Ichthyopl Herpetol 1:218-239. Allen Press, Lawrence, KS

Ozawa T (1986) Studies on the oceanic ichthyoplankton in the western North Pacific. Kyushu University Press, Fukuoka

Platt T, Denman K (1978) The structure of pelagic marine ecosystems. Rapp P-V Reun Cons Int Explor Mer 173:60-65

Rissik D, Suthers IM (2000) Enhanced feeding by pelagic juvenile myctophid fishes within a region of island-

Editorial responsibility: Otto Kinne (Editor-in-Chief), Oldendorf/Luhe, Germany induced flow disturbance in the Coral Sea. Mar Ecol Prog Ser 203:263-273

Rissik D, Suthers IM, Taggart CT (1997) Enhanced zooplankton abundance in the lee of an isolated reef in the south Coral Sea: the role of flow disturbance. J Plankton Res 19: $1347-1368$

Rodriguez J, Mullin MM (1986a) Diel and interannual variation of size distribution of oceanic zooplanktonic biomass. Ecology 67:215-222

Rodriguez J, Mullin MM (1986b) Relation between biomass and body weight of plankton in a steady state oceanic ecosystem. Limnol Oceanogr 31:361-370

Röpke A (1993) Do larvae of mesopelagic fishes in the Arabian Sea adjust their vertical distribution to physical and biological gradients? Mar Ecol Prog Ser 101:223-235

Sheldon RW, Sutcliffe WH, Paranjape MA (1977) Structure of pelagic food chain and relationship between plankton and fish production. J Fish Res Board Can 34:2344-2355

Smith K, Suthers IM (1999) Displacement of Sydney shelf ichthyoplankton by a coastal upwelling event. Mar Ecol Prog Ser 176:49-62

Sprules W, Goyke A (1994) Size-based structure and production in the pelagia of Lakes Ontario and Michigan. Can J Fish Aquat Sci 51:2603-2611

Sprules WG, Bergstrom B, Cyr H, Hargreaves BR and 5 others (1992) Non-video optical instruments for studying zooplankton distribution and abundance. Arch Hydrobiol 36: 45-58

Stapp P, Polis GA, Pinero FS (1999) Stable isotopes reveal strong marine and El Niño effects on island food webs. Nature 301:467-469

Suthers IM (1996) Spatial variability of recent otolith growth and RNA indices in pelagic juvenile Diaphus kapalae (Myctophidae): an effect of flow disturbance near an island? Mar Freshw Res 47:273-282

Suthers IM, Kelley D, Taggart CT, Middleton JH, Rissik D (2004) Entrainment and advection in an island's tidal wake, as revealed by light attenuance, zooplankton, and ichthyoplankton. Limnol Oceanogr 49:283-296

Taggart CT, Thompson KR, Maillet GL, Lochmann SE, Griffin DA (1996) Abundance distribution of larval cod (Gadus morhua) and zooplankton in a gyre-like water mass on the Scotian Shelf. In: Watanabe Y, Yamashita Y, Oozeki Y (eds) Survival strategies in early life stages of marine resources. Balkema, Rotterdam, p 155-173

Vidondo B, Prairie YT, Blanco JM, Duarte CM (1997) Some aspects of the analysis of size spectra in aquatic ecology. Limnol Oceanogr 42:184-192

Williams DM, English S (1992) Distribution of fish larvae around a coral reef: direct detection of a meso-scale, multi-specific patch? Cont Shelf Res 12:923-937

Williams DM, Dixon P, English S (1988) Cross-shelf distribution of copepods and fish larvae across the central Great Barrier Reef. Mar Biol 99:577-589

Woodd-Walker RS, Gallienne CP, Robins DB (2000) A test model for optical plankton counter (OPC) coincidence and a comparison of OPC-derived and conventional measures of plankton abundance. J Plankton Res 22:473-483

Zhou M, Huntley M (1997) Population dynamics theory of plankton based on biomass spectra. Mar Ecol Prog Ser 159:61-73

Submitted: September 26, 2005; Accepted: March 1, 2006

Proofs received from author(s): August 31, 2006 